\title{
Temperature-Pressure Studies on Magnesium-Activated Adenosinetriphosphatase from Skeletal Muscle
}

\author{
JAMES A. WIISON ${ }^{1}$ aND KARI, F. GUTHE. \\ From the Department of Zoology, University of Michigan, Ann Arbor, Michigan \\ Received June 16, 1961

\begin{abstract}
The effects of pressure, temperature, and $\mathrm{pH}$ on the antivity of purified rabbit the amount of pressure applied and is largest at the optimum $\mathrm{pH}$ of the enzyme.
\end{abstract} \\ skeletal muscle magnesium-activated ATPase were measured. The enzyme is rapidly \\ and irreversibly inactivated by both temperature and pressure and shows no evi- \\ dence of muersible denaturation. The extent of irreversible inactivation depends on
}

\section{INTRODUCTION}

Kielley and Meyerhof (1) first isolated a magnesium-activated adenosinetriphosphatase (ATPase) from rat skeletal muscle and later reported the preparation of a similar enzyme from rabbit muscle (2). It is a lipoprotein whose activity is destroyed by lecithinase from Clostridium welchii (2). Muscle Mg-A'LPase is associated with submicroscopic granules in the sarcoplasm (3, 4). Mg-ATPases from red and white fowl muscle have recently been compared (5). Ebashi et al. (6) reported that muscle MgATPase acted as a relaxing factor, but its mode of action in fresh muscle has not been established.

The ATPase activity of myosin, which is calcium-activated, shows characteristic reversible changes with temperature (7) and pressure $(8)$. The interrelation of these effects with each other and with $\mathrm{pH}(9)$ indicates that the enzyme undergoes a reversible change in configuration or conformation, which is sensitive to $\mathrm{pH}$. The present study was designed to see whether the magnesiumactivated ATPase undergoes a similar configurational change and whether its temperature-pressure-pH relations show any of the reversible properties that characterize such relations in glycerated or fresh muscle [reviewed in (10)].

${ }^{1}$ Present address: Department of Zoology, Ohio University, Athens, Ohio.

\section{MATERIALS AND METHODS}

Preparation of Mg-ATPase

The method of preparation was modified slightly from that of Kielley (3). A rabbit was killed by concussion and bled. The psoas muscles were minced in a prechilled meat grinder. Fifty grams of mince was suspended in $400 \mathrm{ml}$. of $0.05 \mathrm{M} \mathrm{KCl}$ and $0.001 \mathrm{M} \mathrm{NaCN}$. The material was blended for $2 \mathrm{~min}$. in a Waring blendor and then stood in the refrigerator for $15 \mathrm{~min}$. The suspension was centrifuged for $15 \mathrm{~min}$. at $3000 \times g$ to remove debris (Servall refrigerated centrifuge, with SS-1 rotor). To every $100 \mathrm{ml}$. of supernatant fluid was added 27 g. ammonium sulfate. After the $\mathrm{pH}$ was adjusted to 8.0 with ammonium hydroxide, the material was stirred for $15 \mathrm{~min}$. and then centrifuged at $10,000 \times g$ for $10 \mathrm{~min}$. The sediment was dissolved in $100 \mathrm{ml}$. of the original extraction medium and centrifuged at $6000 \times g$ for $10 \mathrm{~min}$. to remove larger particles.

To the supernatant fluid was added an equal volume of ammonium sulfate solution $(54 \mathrm{~g} . / 100$ ml.). This material was eentrifuged for $10 \mathrm{~min}$. at $10,000 \times g$, and the sediment was dissolved in 50 $\mathrm{ml}$, of $0.06 . M$ histidine buffer, $\mathrm{pH} 7.4$, containing $0.3 \mathrm{M} \mathrm{KCl}$ and $0.001 . M \mathrm{XaCN}$. Any insoluble material was removed by centrifugation at $10,000 \times g$ for $10 \mathrm{~min}$. The supernatant fluid was then centrifuged for $2 \mathrm{hr}$. at $30,000 \times g$, and the sediment from this centrifugation was resuspended in 50 $\mathrm{ml}$. of the histidine- $\mathrm{KCl}$ buffer. This solution was centrifuged for $15 \mathrm{~min}$. at $30,000 \times g$, and the supernatant was used in experimental studies after fivefold dilution with the histidine- $\mathrm{KCl}$ buffer. All steps in the preparation wcre carried 
out at $0^{\circ} \mathrm{C}$. Deionized distilled water was used throughoul.

\section{Determination of Enzyme Activity}

Two milliliters of enzyme solution and $0.1 \mathrm{ml}$. of $0.123 M \mathrm{MgSO}_{4}$ were incubated in a water bath for $5 \mathrm{~min}$. After incubation, $2 \mathrm{ml}$. of $7.2 \mathrm{mM}$ ATP (crystalline disodium salt, Pabst Laboratories) was added. The reaction mixtures contained the following concentrations unless otherwise stated : $0.06 M$ histidine ( $\mathrm{pH} 7.4), 0.3 \mathrm{M} \mathrm{KCl}$, $3.0 \mathrm{~m} M \mathrm{Mg}, 1.0 \mathrm{~m} M \mathrm{NaCN}$, and $3.6 \mathrm{~m} M$ ATP. The reaction was stopped by the addition of 4 ml. of $10 \%$ trichoroacetic acid. Two-milliliter aliquots were used for colorimetric phosphate determinations by the method of Fiske and SubbaRow. All reactions unless otherwise stated were run at $25^{\circ}$ for $30 \mathrm{~min}$.

Activity of the enzymes is expressed as micromoles of phosphorus liberated $/ \mathrm{mg}$. protein $/ \mathrm{min}$. ( $\mu$ moles $\mathrm{P} / \mathrm{mg} . / \mathrm{min}$. ). The protein content was calculated from Kjeldahl or Nessler nitrogen determinations, assuming that the protein was $16 \%$ nitrogen.

\section{Pressure}

Hydrostatic pressure was obtained with a hydraulic pump to which were attached a pressure gage and manifold. Three pressure bombs each capable of containing three 4-ml. test tubes could be connected to the manifold. Pressures were transmitted to the reaction mixtures, in rubber-capped test tubes, through the pressure fluid in which the tubes were suspended. Pressure was increased from atmospheric to its experimental value in less than 15 sec., and was reduced back to atmospheric in about 1 sec. It was usually applied for $10 \mathrm{~min}$. in a total reaction time of $30 \mathrm{~min}$. The number of micromoles of phosphate liberated was corrected for the time that the reaction mixture spent at atmospheric pressure.
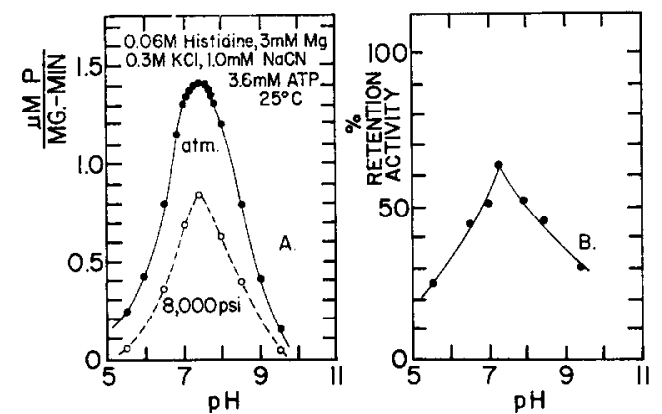

Fig. 1. (A) Dependence of muscle Mg-ATPase activity on $\mathrm{pH}$. (B) Per cent retention of activity at $8000 \mathrm{lb} . / \mathrm{sq}$. in. and different $\mathrm{pH}$.

\section{RESULTS}

\section{General Properties}

The described method of preparation was adopted because it removed all calciumactivated ATPase activity, which appeared to be the chief contaminant. Several paperelectrophoresis studies showed only a single band which migrated toward the anode. It was concluded that, within the limits of this analytical method, the preparations contained only a single component.

Hydrolysis of adenosine triphosphate (ATP) was measured after incubation times of 1 to $120 \mathrm{~min}$. and found to be linear. Extended hydrolysis for $4-5 \mathrm{hr}$. showed that only the terminal phosphate was removed. The activity of the material increased during the first few days after preparation and then decreased, until after about 1 week all activity was lost, as described by Kielley (3). All measurements were made in the presence of saturating concentrations of ATP.

Altering the magnesium concentration (with other components of the reaction mixture held constant) showed that activity rose sharply to an optimum at $3 \mathrm{~m} M \mathrm{Mg}^{++}$ and then decreased slowly. Calcium inhibited all concentrations. At $3 \mathrm{~m} M \mathrm{Mg}^{++}$, varying $\mathrm{KCl}$ showed optimal activity at $0.3 M \mathrm{KCl}$ and gradual decreases in more concentrated or more dilute solutions. There was no indication of a salt effect on solubility in the range of 0 to $1 \mathrm{M} \mathrm{KCl}$.

\section{$\mathrm{pH}$ Dependence}

Muscle Mg-ATPase showed a $\mathrm{pH}$ optimum at 7.4 (Fig. $1 A$ ) in histidine buffer. The Mg-ATPase activity of granules from rat muscle were reported (4) to have an optimum at $\mathrm{pH} 7.4$ in glyoxaline buffer and at $\mathrm{pH} 8$ in borate buffer. However, Kielley and Meyerhof (2) found an optimum at $\mathrm{pH}$ 6.8, and the reasons for this difference are unknown. Even under the same experimental conditions as those of the above authors, the $\mathrm{pH}$ optimum of our preparations was 7.4 at all temperatures in the range $10-40^{\circ} \mathrm{C}$. Although several Mg-ATPases might exist in rabbit muscle, $\mathrm{pH}-\mathrm{ac}-$ tivity curves of crude fractions from early 
stages in the enzyme preparation revealed only the $\mathrm{pH} 7.4$ optimum.

\section{Temperature-Pressure}

The increase of activity with increasing temperature followed the Arrhenius relationship only up to $25^{\circ} \mathrm{C}$. (Fig. 2). The apparent heat of activation, $\Delta H^{*}$, was $16,200 \mathrm{cal} . / \mathrm{mole}$ in the range $2-20^{\circ}$. Optimum activity occurred at about $40^{\circ}$. Howcver, the enzyme was irreversibly inactivated at all temperatures. After $2 \mathrm{~min}$. incubation at a higher temperature, without substrate or magnesium ion, the enzyme always showed less activity than after incubation at the temperature of the activity delermination. Incubation of enzyme with substrate but without $\mathrm{Mg}$ provided only slight protection against irreversible inactivation.

Hydrostatic pressure decreased activity under all conditions, and this pressure inactivation was also completely irreversible. The plot of logarithm of rate against pressure was linear (Fig. 3B). Because different preparations of enzyme varied in absolute activity as activity changed with age, only one set of points is shown in most of the figures. However each experiment was repeated at least thrce times in triplicate, and the shapes of the curves as well as the optima were the same. Although the three curves of Fig. $3 B$ represent three different preparations with different absolute ac-

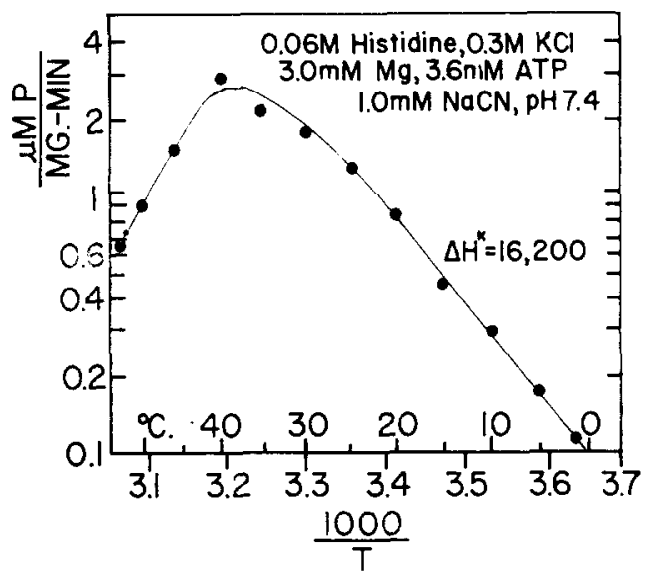

FIG. 2. Temperature dependence of muscle $\mathrm{Mg}$ ATPase activity.

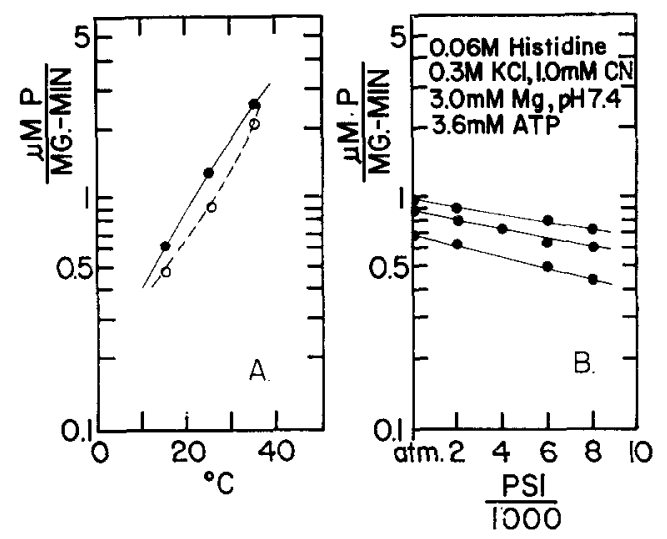

Fig. 3. Pressure dependence of muscle $\mathrm{Mg}$ ATPase activity. (A) Comparison of activity at atmospheric pressure (solid curve) and at 8000 lb./sq. in. (dashed curve) at different temperatures. (B) Influence of increasing pressures at $25^{\circ}$ on three different preparations of muscle Mg-ATPase.

tivities, the slopes of the three lines are similar, and at $25^{\circ}$ and $8000 \mathrm{lb}$. $/ \mathrm{sq}$. in. the inhibition in each case was about $30 \%$. Inhibition by pressure was less at $15^{\circ}$ or $38^{\circ}$ than at $25^{\circ}$ (Fig. $3 A$ ).

Figure $1 A$ shows that $8000 \mathrm{lb} . / \mathrm{sq}$. in. inhibited less at the $\mathrm{pH}$ optimum of 7.4 than at either end of the $\mathrm{pH}$ curve. This region of maximum stability is shown more clearly in Fig. $1 B$ where the per cent of activity retained at $8000 \mathrm{lb} . / \mathrm{sq}$. in. is plotted against the $\mathrm{pH}$. The symmetry of the $\mathrm{pH}$ curves at both pressures supports the conclusion that only a single active component is present.

The irreversibility of the pressure effect and its logarithmic dependence on pressure suggested that pressure might be affecting a rate process rather than an equilibrium. However, varying the time of reaction under pressure between $30 \mathrm{sec}$. and $1 \mathrm{hr}$. produced no change in the extent of inhibition. The activity of the enzyme was also tested after it had been exposed to pressure in the absence of substrate or activator. Whether substrate or activator was present or absent, the extent of pressure inhibition was the same. Tests $3 \mathrm{hr}$. after pressing showed activity had not recovered.

\section{DISCUSSION}

The rapid and irreversible effects of moderate temperature and pressure on the ac- 
tivity of muscle $\mathrm{Mg}$-ATPase are in sharp contrast to the reversible effects of these agents on myosin (7-9), on most other enzymes studied $[(11) ;(12)$, p. 315$]$, and on the contraction and relaxation of fresh muscle and glycerated fibers (10). The irreversibility of the pressure effect makes it impossible to interpret the effect as a result of the direct action of pressure on an equilibrium, and the failure to find any further change after 30 sec. rules out a simple effect on the rate of irreversible denaturation. Chymotrypsinogen (13) responds similarly to pressure, however, at much higher pressures (up to $135,000 \mathrm{lb}$./sq. in.). The mechanism suggested for chymotrypsinogen inactivation may also apply here. According to Curl and Jansen (13), application of pressure may convert a pressure-sensitive molecule (E) to either of two pressure-insensitive forms, which are active $\left(\mathrm{E}_{a}\right)$ or inactive $\left(\mathrm{E}_{i}\right)$ enzymically. The present results indicate that ncither of thesc forms reverts to the pressure-sensitive form during the experiment.

$$
\mathrm{E}_{a} \longleftarrow \mathrm{E} \longrightarrow \mathrm{E}_{i}
$$

The relative amounts of $\mathrm{E}_{a}$ and $\mathrm{E}_{i}$ will depend on their relative rates of formation, which in turn depend on pressure, the rate of formation of $\mathrm{E}_{i}$ being accelerated with pressure relative to the rate of formation of $\mathrm{E}_{a}$. A similar but more extensive analysis has been applied [(12), p. 213] to the irreversible denaturation of luciferase by temperature.

Whatever the mechanism of action of pressure on muscle Mg-ATPase, the irreversibility of the effect raises problems in connection with the reversibility of temperature-pressure effects in fresh muscle and glycerated fibers (10), since the enzyme acts as a relaxing factor $(6)$.

At least two explanations for the lack of irreversible effects in muscle are possible: (a) The enzyme may be present in excess of the demands of the system, so that its inhibition only decreases the margin of safety. (b) The enzyme may be protected against irreversible changes in configuration by interaction with other proteins or lipoproteins. The small size of the pressure effect suggests that there are only slight struc- tural differences between the active and inactive forms, so that stabilization would not require extensive interaction. Enhancement of hexokinase activity by binding to mitochondria indicates that interactions of enzymes with structural elements may be very significant $(15,16)$, and the effects of surface-spreading on enzyme activity have been emphasized (17).

\section{ACKNOWLEDGMENT}

Many helpful discussions with Dr. D. E. S. Brown are gratefully acknowledged.

\section{REFERENCES}

1. Kielley, W. W., ANd Meyerhof, O., J. Biol. Chem. 176, 591 (1948).

2. Kielley, W. W., and Meyerhof, O., J. Biol. Chem. 183, 391 (1950).

3. Kielley, W. W., in "Methods in Enzymology," (S. P. Colowick and N. O. Kaplan, eds.), Vol. 2, p. 588. Academic Press, New York, 1955.

4. Prrry, S. V., Biochim. et Biophys. Acta 8, 499 (1954).

5. Tonzetich, J., and Kare, M. R., Arch. Biochem. Biophys. 86, 195 (1960).

6. Ebashi, S., Takeda, F., Otsuka, M., and KumaGaI, H., Symposia on Enzyme Chem. 11, 11 (1956).

7. Levy, H. M., Sharon, N., and Koshland, D. E., JR., Biochim. et Biophys. Acta 33, 288 (1959).

8. Laidler, K. J., and Beardell, A. J., Arch. Biochem. Biophys. 55, 138 (1955).

9. Browx, D. E. S., Gurhe, K. F., Lawler, H. C., and Carpenter, M. P., $J$. Cellular Comp. Physiol. 52, 59 (1958).

10. Brown, D. E. S., in "The Influence of Temperature on Biological Systems," (F. H. Johnson, ed.), p. 83. Amer. Physiol. Soc., Washington, D. C., 1957 .

11. Laidler, K. J., Arch. Biochem. 30, 226 (1951).

12. Johnson, F. H., Eyring, H., AND Polissar, M. J., "The Kinetic Basis of Molecular Biology," John Wiley and Sons, New York, 1954.

13. Curl, A. L., and Jansen, E. F., J. Biol Chem. 185, 713 (1950).

14. Chase, A. M., J. Gen. Physiol. 33, 535 (1950).

15. Sifkevitz, P., Axd Potter, V. R., J. Biol. Chem. 215, 237 (1955).

16. Siekevitz, P., in "Regulation of Cell Metabolism, CIBA Foundation Symposium," (G. E. W. Wolstenholme and C. M. O'Connor, eds.), p. 17. Iittle, Brown \& Co., Boston, Mass., 1959.

17. Hayashi, T., Am. Naturalist 87, 209 (1953). 